\title{
AS ÁGUAS DO RIO CAÍ COMO GUIAS: ENCONTRO COM MARCOS AMBIENTAIS DO DESENVOLVIMENTO PETROQUÍMICO BRASILEIRO
}

\author{
Claudia Ribeiro \\ Elenita Malta Pereira ${ }^{2}$
}

\section{Introdução}

Este trabalho é possível pela parceria existente entre dois caminhos acadêmicos singulares. O modo pelo qual ocorreu este encontro de trajetórias foi altamente favorável a tal sinergia de interesses, enquanto, de outro lado, o domínio intrincado que é foco da ação de estudo tem sido outro fator estimulante a passos que já almejavam por eles próprios transposições de atuações estritamente disciplinares.

Estamos reconstituindo a história ambiental do Complexo Petroquímico do Sul, o terceiro deste tipo no Brasil, construído no município de Triunfo, no Rio Grande do Sul (RS). Configura-se assim um campo de exploração a partir dos resultados obtidos pelos cotejamentos críticos com os estudos do desenvolvimento e da engenharia química. A pesquisa integra o projeto “Água, Saúde e Ambiente na História de Projetos de Desenvolvimento no Brasil do Século XX”, liderado por equipe da Casa de Oswaldo Cruz (COC-Fiocruz), em construção que paulatinamente organiza-se em torno de nosso principal questionamento, que é realizar a análise dos embates que ocorreram desde que o Polo foi anunciado, em 1975, como um projeto situado em pleno contexto desenvolvimentista da ditadura civil-militar. Grosso modo, de um lado estavam os grupos defensores do empreendimento, justificando que este traria melhorias à economia do Estado. De outro, seus opositores, denunciando seu potencial poluidor, com especial preocupação com as águas do estuário do Guaíba, que abastecem a população de Porto Alegre.

Cumpre pois, explicar os detalhes destas trajetórias e o modo pelo qual ocorreu tal encontro. Posteriormente, esta contribuição mostra o local que sedia esta ação de conhecimento, pela descrição de nosso trabalho de campo. Nos acervos acessados, preciosos arquivos imagéticos foram encontrados, permitindo construir a narrativa que aqui apresentamos. Fiéis a nós mesmas, decidimos contar esta história por uma das

\footnotetext{
${ }^{1}$ Universidade Federal do Rio Grande do Sul, Brasil. E-mail: cribeiro.pareci@terra.com.br ORCID id: http://orcid.org/0000-0001-5486-4187

${ }^{2}$ Universidade Estadual do Centro Oeste, Brasil. E-mail: elenitamalta@gmail.com

ORCID id: http://orcid.org/0000-0001-9835-391X
} 
linhas que aqui nos trouxeram: a das águas que banham a cidade que tem nome de Porto Alegre. Por fim, teceremos algumas considerações a respeito deste percurso e de seus achados.

\section{As pesquisadoras}

Primeiramente, por relevância ao caráter científico deste artigo, cabe apresentar-nos, explicando os caminhos que nos levaram ao projeto de pesquisa que atualmente desenvolvemos em conjunto. Tal parceria principia quando cursamos a disciplina Tecnociência, Natureza e Desenvolvimento, ministrada pelo professor Jalcione Almeida, no Programa de Pós-Graduação em Desenvolvimento Rural da Universidade Federal do Rio Grande do Sul (PGDR). Nas manhãs de sexta-feira do primeiro semestre de 2012, o coleguismo consolidou-se aos poucos. Na mesma instituição, tínhamos formações muito diferentes: engenheira química e mestranda no PGDR e historiadora e doutoranda no Programa de Pós-Graduação em História.

Não obstante este aspecto, gradativamente identificamos interesses comuns, afinidades empáticas de vidas femininas em seu desenrolar variado. Deste modo, fomos entremeando conversas motivadas pelos assuntos decorrentes das aulas e suas correlatas discussões em relação aos nossos projetos acadêmicos, com aquelas derivadas do cotidiano da maternidade e sua compatibilidade com inúmeros outros aspectos de nossas vivências. Também a execução em dupla de um dos 'temas' da disciplina deu- nos um primeiro motivo pragmático para a descoberta de pontos de convergência de pensamento e de ética profissional. Caminho sem dúvida consolidado pelo compartilhamento de nossas experiências de trabalho na esfera local: na indústria petroquímica, nos sistemas de proteção aos recursos hídricos e na pesquisa histórica.

Ao final de 2017, depois de um intervalo sem notícias uma da outra, retomamos o contato e acordamos as possibilidades de colaboração na pesquisa já em curso: sobre os embates ambientais causados pela construção do Polo, entre os anos de 1975-1982, acessando referenciais teóricos da história ambiental e dos estudos do desenvolvimento, pelo viés de análise dos conflitos ambientais.

Neste quadro consolida-se o interesse mútuo pelo exame da ambientalização em torno da proteção das águas nas proximidades de Porto Alegre. Fenômeno em sua generalidade remarcado por Gerhardt e Almeida (2005:6) como historicizado, pois emergindo de contexto temporalmente específico, é descrito por Acselrad (2010:103) como sendo a "[...] adoção de um discurso ambiental genérico por parte dos diferentes 
grupos sociais, como a incorporação concreta de justificativas ambientais para legitimar práticas institucionais, políticas, científicas, etc. [...]”.

Em reflexão que rememora sua experiência na bacia do rio Cubatão (região da grande Florianópolis em Santa Catarina), Silva (2000:77) pontua a emergência de característica comum às várias abordagens desse discurso na década de 1970, já dizendo da "insuficiência do conhecimento fragmentado para o tratamento da complexidade ambiental". Posição bastante próxima ao conceituado por Floriani (2000: 100 e 101), já em interpenetração com a temática do desenvolvimento, a partir da experiência conduzida na Universidade Federal do Paraná. Reconhece o autor nesse caso a necessidade de prática interdisciplinar com "uma intenção deliberada, assentada em trocas subjetivas sistemáticas, a partir do confronto de saberes disciplinares, que leve em conta uma ou mais problemáticas na relação sociedade-natureza".

Situamos desse modo nossa trilha de estudo interdisciplinar, rumo que sabemos ao menos indicado para esforços no âmbito da complexidade das relações entre grupos de seres humanos e seus entornos de vida. Recorrido que principia pela constituição inicial de acordos internos e seguimento dos rumos de ação decididos a partir disso. Como resultado iniciamos a visualizar contornos de rede constituída de elementos de naturezas distintas e fluxos comunicativos múltiplos e intrincados. Um permanente desafio, ao mesmo tempo em que instigante oportunidade de descoberta de novos ângulos de abordagem e reflexão nessa ação de conhecimento por nós priorizada.

Do conjunto de nosso modus operandi, a contribuição detalha uma etapa que julgamos fundamental para entendimento mútuo das diversas possibilidades de aprofundamento da pesquisa, tanto pela descoberta e acesso aos acervos de fontes, como pela percepção in loco dos locais relacionados aos fatos que mais bem queremos entender, procedimento de capital influência nas delimitações de espaço e tempo enfim efetuadas em nosso estudo.

\section{Intenções e contornos da ação de conhecimento}

Consideramos como o primeiro marco temporal do III Polo Petroquímico o anúncio definitivo de sua realização no Rio Grande do Sul, em 26 de agosto de 1975. Importante sublinhar que esta decisão, bem como outras principais atitudes relativas ao Polo, foi tomada por generais e civis afinados com o projeto econômico em vigor, por meio do II Plano Nacional de Desenvolvimento (PND). E que Ernesto Geisel, neste 
contexto, foi influência política determinante na escolha do RS, seu estado natal, para sediar o empreendimento.

O emprego do termo ‘desenvolvimento' pelos seus articuladores na época, além de alegar a necessidade de empregos (crescimento econômico) utilizava argumentos associados à ideia de crescimento. Nesta circunstancial visão, seria um movimento estimulado pela atuação estatal e deveria promover a transformação estrutural da sociedade (Almeida, 1997:34 e 36, itálico no original).

Tal comunicação que logo deu início a um processo reservado de discussões em torno de sua microlocalização municipal, sacramentada em 09 de outubro de 1975 no município de Triunfo, a $30 \mathrm{~km}$ de Porto Alegre (RS, Decreto 24.113, 1975). Decisão que aporta o primeiro subsídio de concretude espacial ao empreendimento.

Se para tais empreendedores esse pretendido local geográfico resolvia a grande necessidade de água doce para o funcionamento do processo industrial e a logística de proximidade com a refinaria Alberto Pasqualini, a já existente articulação ambientalista na sociedade gaúcha externou de pronto os riscos associados à contaminação das águas que seriam utilizadas pelo então planejado aglomerado petroquímico, opondo-se vigorosamente contra os resultados de tal deliberação.

Por essa decisão, o aglomerado industrial teve sua construção definida na margem direita do rio Caí, no seu trecho inferior, pouco antes de sua foz no rio Jacuí. Portanto, águas acima de Porto Alegre, inerentemente ameaçando as suas captações para o tratamento de água potável da população da capital: que passa a ser, na abrangência de sua região metropolitana, outra incidência espacial muito importante na celeuma que decidimos estudar, como evidencia o mapa 1, disposto na próxima página.

Além de o processo decisório da escolha da sede do Complexo não ter sido conduzido publicamente, o teor desse anúncio primordial não foi acompanhado sequer de incipiente ideia de solução para o espinhoso problema do tratamento e disposição final dos resíduos que seriam gerados (em especial, no que tange aos efluentes líquidos). De outra parte, externando sua profunda preocupação com a poluição das águas que poderia ser aportada pelo empreendimento, seus opositores conseguiram que uma suposta exclusiva decisão técnica sobre o tratamento dos efluentes pudesse ser transformada em campo público de debate por leigos já engajados no movimento ambientalista. 
Mapa 1 (autoria de Claudia Ribeiro e elaboração de Silvia Aurelio, 2019)

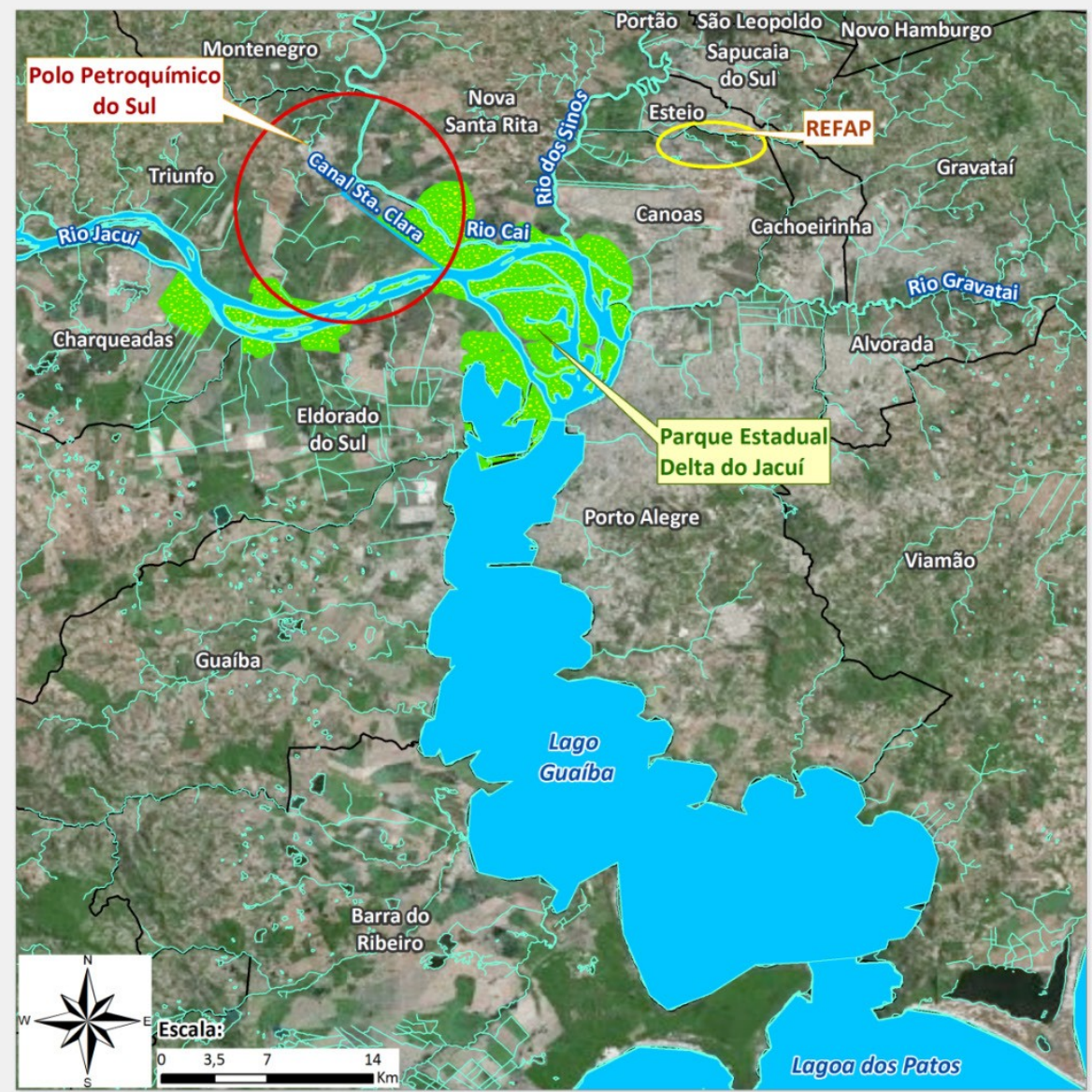

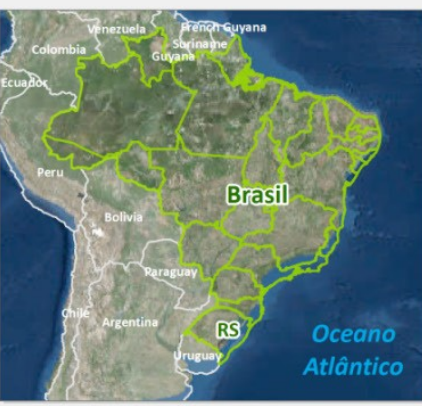

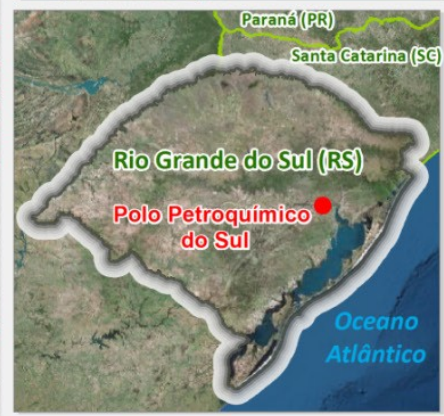

Legenda

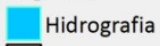

$\square$ Municípios

Parque Delta do Jacui

Polo Petroquímico do Sul

Refinaria Alberto Pasqualini - REFAP Dados Cartográficos:

Sistema de Projeção

Universal Transversa de Mercator (UTM) Datum SIRGAS 2000, Fuso 22 Sul.

Localização da área de estudo.

Assim, a partir desta época até o início das operações do aglomerado industrial em 1982, fomos acompanhando tal impasse técnico-social. Um acirrado cruzamento de toda uma gama de argumentos favoráveis e contrários, ao longo da cogitação de sua série de soluções, na sucessão de seus respectivos comunicados e discussões no âmbito público - desde tubos gigantescos que levariam os efluentes líquidos ao oceano Atlântico, ou ao lago Guaíba, ou à lagoa dos Patos, até a decisão de construir-se uma estação que faria o tratamento em três etapas e, ao final, disporia o material disso proveniente (o efluente tratado e o resíduo sólido resultante) no solo do próprio empreendimento. (Pereira, Ribeiro, 2021, no prelo). 
Consoante a essa trajetória, portanto, definimos o início das atividades do III Polo Petroquímico como marco final de nosso recorte histórico de pesquisa, que ficou definido como o período 1975-1982. Transcurso de tempo no qual acontece o projeto e o funcionamento do seu Sistema Integrado de Tratamento de Efluentes Líquidos (SITEL), construído (e gerido até hoje) pela Companhia Riograndense de Saneamento (CORSAN), em importante coincidência à fase de início do processo de abertura política da ditadura civil-militar brasileira.

\section{Impressões de um trabalho de campo}

Desde o tenro início dessa nossa ação de conhecimento, acervos de documentação escrita e fontes orais foram perscrutados em procuras coerentes ao esclarecimento do embate em torno do empreendimento, como já detalhado, nossa principal pergunta. Assim, já havíamos constituído um banco de documentos que permitiu-nos entender melhor o trabalho dos técnicos encarregados da construção do SITEL - o grupo formado pela Superintendência para Programas Especiais (SUPE), constituído em 1979 na CORSAN por Paraguassú Garcia Flores, Ellen Martha Pritsch, Zeno Simon, Millos Augusto Stringhini e, temporariamente, por Luiz Antonio Timm Grassi e Elaine Pires Duarte.

Ressaltamos nesse sentido nossa visita à Biblioteca Pública da FEPAM (BPFEPAM), realizada em 20 de dezembro de 2017. Juntamente com toda uma série de documentos prévios à construção do Polo (com especial foco aos relacionados à concepção do SITEL), a BFEPAM guarda os únicos registros disponíveis ao público dos dois Estudos de Impacto Ambiental-Relatório de Impacto Ambiental (EIA-RIMA) produzidos sobre o Polo Petroquímico do Sul, como testemunham as fotografias 1 e 2 . 
Fotografias 1 e 2 (autoras, 2017)

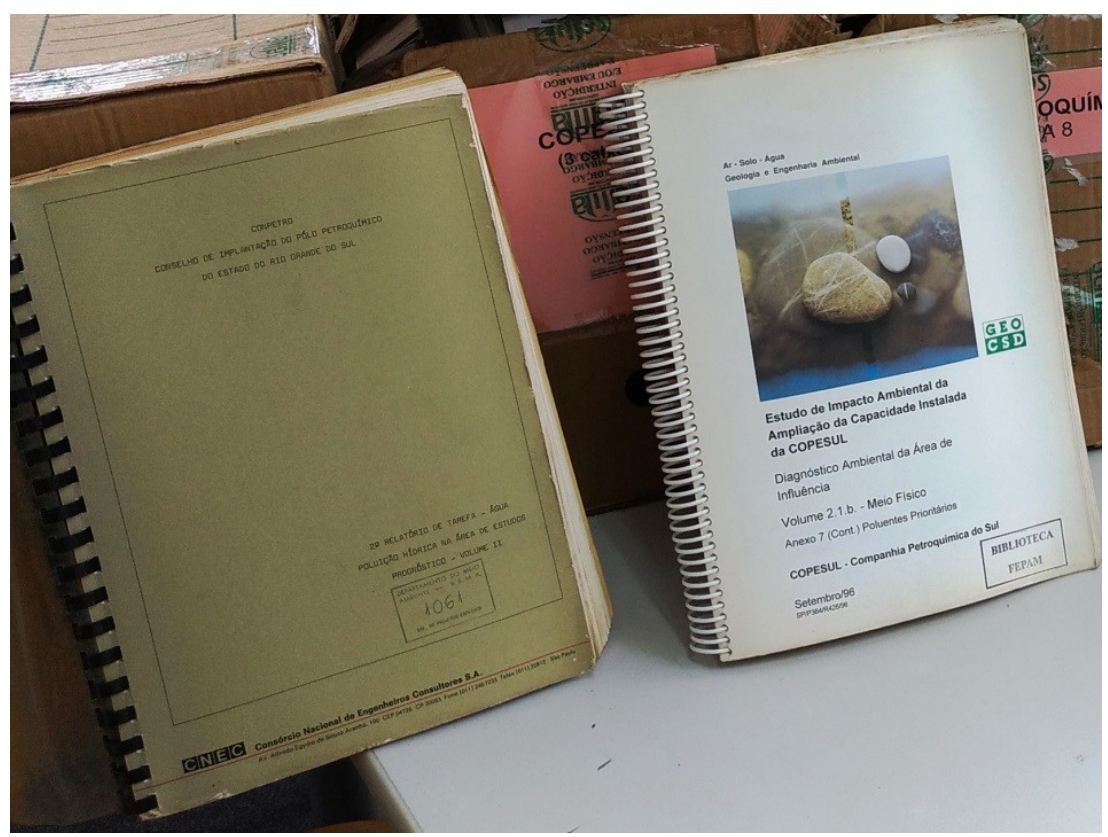

Volume do único exemplar público do primeiro EIA/RIMA do Brasil, em conjunto com amostra de seu sucedâneo, requerido nos trâmites de licenciamento ambiental para a ampliação do Complexo Petroquímico.

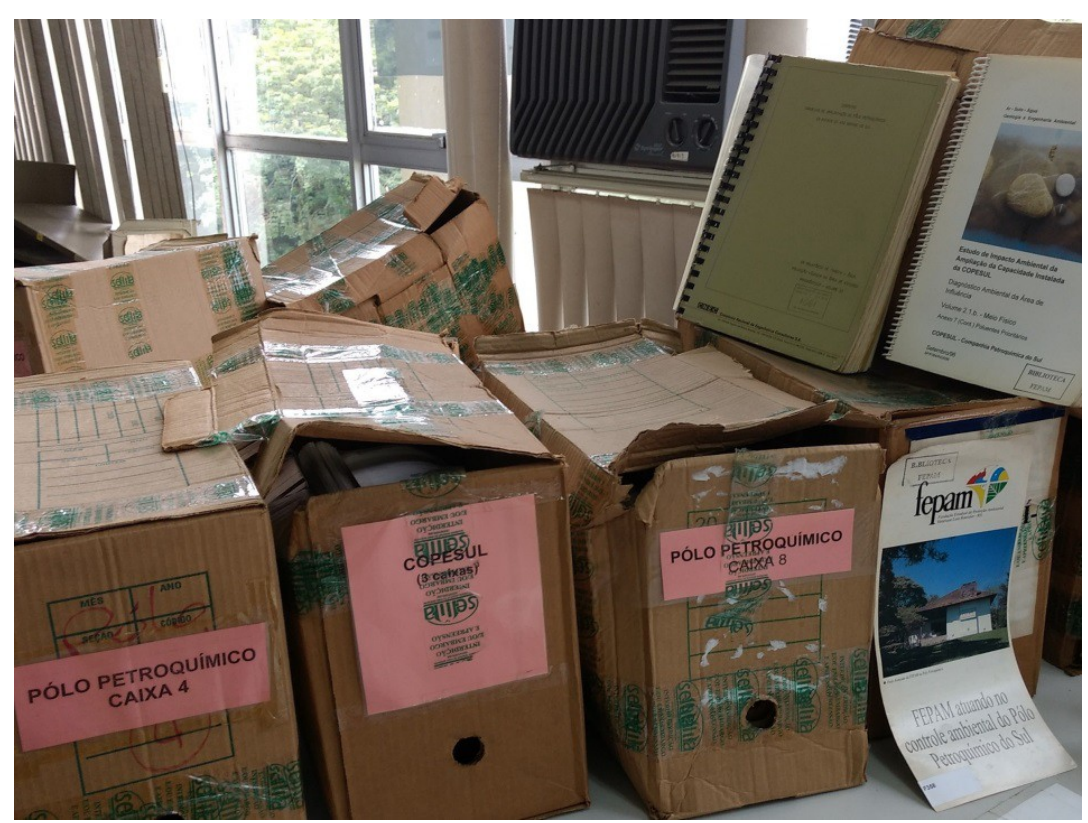

Acervo da FEPAM relativo ao Polo Petroquímico de Triunfo. 
Tal acesso foi obtido mediante agendamento prévio. Na ocasião fomos muito bem atendidas pela bibliotecária Sílvia Jungblut, que já separara previamente os documentos que solicitamos analisar. O primeiro, de 1979/1980, foi chamado na época de "Relatório Técnico Preliminar" (RTP). Sendo composto de diversos volumes, divididos em Tarefas (Água, Ar, Solo) é um conjunto produzido pelo Consórcio Nacional de Engenheiros Construtores S/A, empresa contratada para realizá-lo. Trata-se de estudo muito importante para nossa compreensão do debate técnico que levou à opção pelo SITEL e as primeiras etapas de sua elaboração. Este corpus técnico é considerado o primeiro EIA-RIMA do Brasil - ainda não com esse nome, pois não existia ainda este conceito, e muito menos a sua obrigatoriedade de realização. Enquanto o segundo, datado de novembro de 1996, foi confeccionado por ocasião do licenciamento ambiental da duplicação do Complexo Petroquímico do Sul, pela CSDGEOKLOCK Geologia e Engenharia Ambiental Ltda.

Como prática subsequente, acordamos ser de fundamental importância uma visita in loco da área enfim construída. No desenho e consecução desta tarefa, combinou-se a antiga familiaridade com a engenharia 'de botinas e capacetes' da agora colega no campo das ciências sociais às facilidades de trânsito da historiadora, habituada às abordagens de acervos documentais de vários tipos e apresentações. Retorno para uma, novidade para a outra, enfim chegava mesmo a hora, pragmática e metafórica, de mais uma vez experimentarmos "comprar par de sapatos resistentes para caminhadas", contudo já sabendo que "não poderemos evitar sujá-los com a lama dos caminhos" (Worster, 1991:199).

Apoiadas portanto na acumulada vivência pregressa nesse terreno, priorizamos a visita ao Complexo, realizada em 15 de janeiro de 2018. Nesta incursão buscamos principalmente adquirir uma visão conjunta sobre os mananciais que foram mobilizados nas discussões, conhecendo a realidade dos pontos de contato do empreendimento com o rio Caí (uma vez que existe também um porto e canal artificial de navegação até o rio Jacuí).

Primeiramente, reconhecemos o conjunto das empresas, por intermédio de nosso autônomo recorrido do anel rodoviário que as engloba. Logo em seguida, fomos até a Casa Rosa, local icônico para a história desse aglomerado industrial. Praticamente a única moradia conservada, das tantas sedes de propriedades rurais que foram compradas para integrar a área industrial, hoje sedia um parque ambiental aberto à visitação pública, 
onde estão os marcos inaugurais das obras de construção do Polo. Em seu entorno foi construída uma das bacias de acumulação e segurança das áreas industriais (que recolhe águas de chuva não contaminadas para ali direcionadas), com deságue para o rio Caí, que pode ser avistado de um pequeno mirante para isso disponibilizado. Próximo dali avistamos de longe o prédio da captação de água para o Complexo: o último ponto correnteza do rio abaixo.

Por fim realizamos, mediante prévio agendamento realizado com o gestor de departamento Daniel Villa, uma visita guiada às instalações do SITEL. Um ponto alto do recorrido, pois é o local que representa a solução do embate por nós estudado. Deste dia fez parte o acesso ao Acervo Público do SITEL (APSITEL), com o apoio de Tatiana Rossato. Nele constam, além de documentos administrativos decorrentes do funcionamento da estação de tratamento, outros vestígios importantes, em registros em muitos casos não disponíveis em formato digital: textos de artigos acadêmicos produzidos pelo Grupo da SUPE, nos anos 1980, e um riquíssimo conjunto imagético, contendo registros fotográficos da obra da estação de tratamento de efluentes, bem como da ocorrência de inúmeras reuniões e apresentações de seu projeto.

Na próxima página, colocando em outra forma do que a deste discurso escrito até aqui disposto, mostramos a composição de fotos de satélite que visualmente demonstra nosso percurso, do rio Caí a Porto Alegre, em progressão paulatina para outro tipo de narrativa desse nosso trabalho de campo. 
Mosaico de fotos 1 (autoria de Claudia Ribeiro e elaboração de Silvia Aurelio, 2020)

Fonte: Service Layer Credits: Esri, HERE, DeLorme, MapmyIndia, OpenStreetMap ${ }^{\mathbb{B}}$ contributors and the GIS community

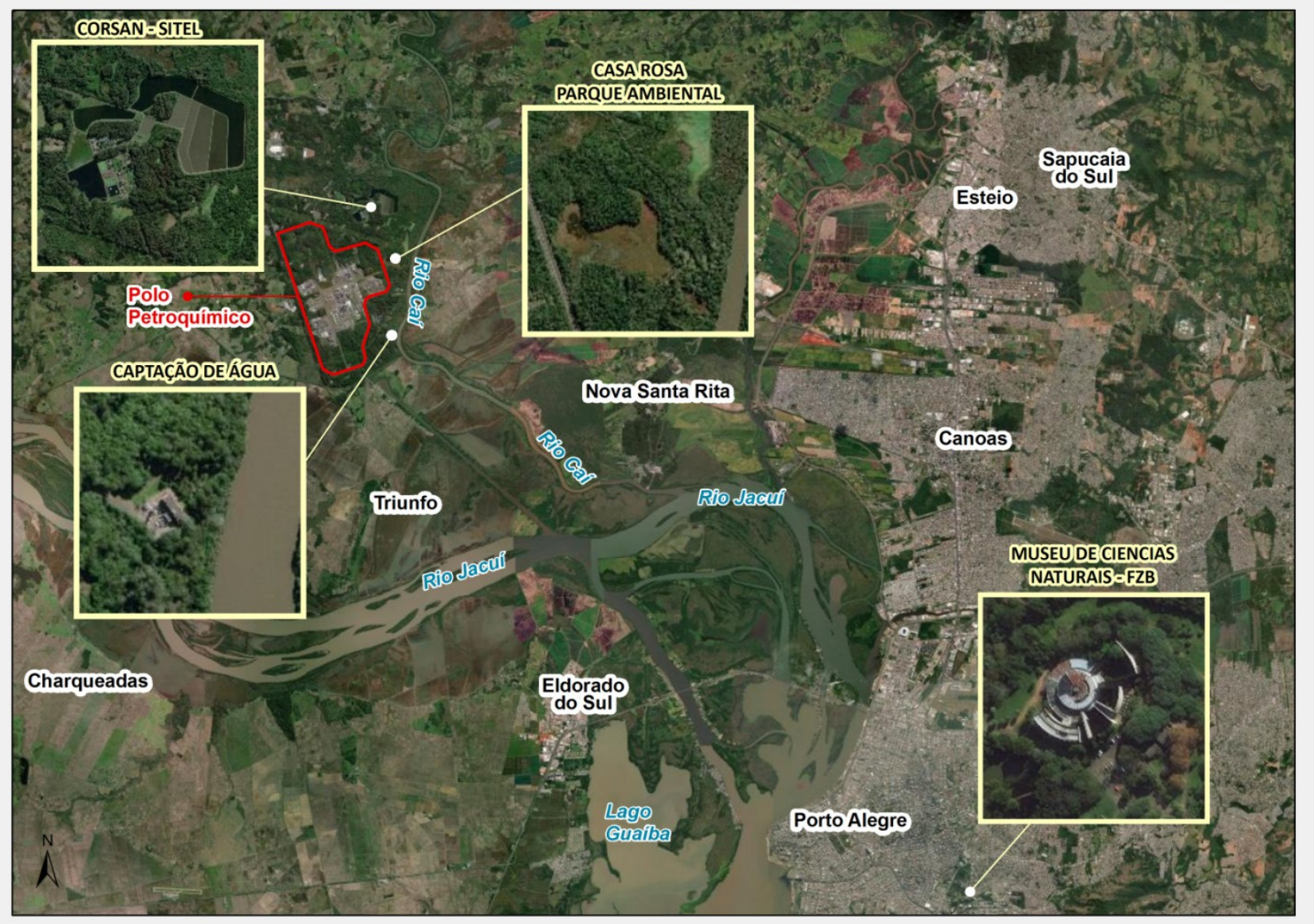

Percurso do trabalho de campo, do rio Caí a Porto Alegre.

Iluminuras, Porto Alegre, v. 21, n. 54, p. 710-741, setembro, 2020.

Percurso do trabalho de campo, do rio Caí a Porto Alegre. 
Reconhecendo nossa sensibilidade ao fato de ter sido a preocupação com as águas que circundam a região metropolitana de Porto Alegre o motor desse debate público, previamente decidimos no dia 15 de janeiro de 2018 prestar muita atenção ao rio Caí, que nesse ponto está quase ao final de seu curso de pouco mais de 200 quilômetros, principiado nas áreas de suas nascentes nos Campos de Cima da Serra. Na totalidade de sua bacia hidrográfica, integra a vida da população de cerca de meio milhão de pessoas e suas atividades variadas, distribuída por 42 municípios. Em sua implantação, o agrupamento de indústrias petroquímicas é, portanto, mais uma de uma infinidade de relações com muitas coisas e organismos nesta trajetória líquida. (RS, 2007a;2007b).

Ainda pela manhã de um dia de céu acinzentado, percorremos uma pequena trilha a partir da Casa Rosa, em rápido trajeto: de tom escuro e correnteza quase imperceptível foram as águas que encontramos, com margens revestidas por vegetação de pequeno porte. Fica difícil identificar por isso que estamos na margem direita (correnteza abaixo), pouco antes de esse rio fundir-se ao muito mais caudaloso rio Jacuí, que logo depois, juntamente com os rios Sinos e Gravataí e alguns vários arroios vai conformar o Guaíba, grande manancial em cujas margens situa-se Porto Alegre.

Não por acaso, por certo, embora não planejado a esse nível de detalhe, nesse momento e lugar iniciamos os registros fotográficos que efetuamos ao total. O olho já tinha alguma informação prévia ao realizar suas escolhas de captura de imagens, como ressalta Milton Guran, antropólogo e fotógrafo que nos fornece subsídios teóricos para situar esta coleção de imagens como um corpus fotográfico. Uma aquisição cuja intenção foi principalmente a de documentar nossa especial incursão empírica em viés de conhecimento interdisciplinar. Entendendo-a bastante apoiada nos domínios das ciências sociais aplicadas, adotamos igualmente a recomendação desse autor, para sua produção de sentido no contexto dessa contribuição e de nosso estudo como um todo: "[...] ela precisa ser lida de forma específica, ou seja, ter seu conteúdo (re)descrito e (re)interpretado através do discurso textual, oral ou escrito" (Guran, 2011: 81).

Como corolário desse trabalho, engendramos a narrativa de predominância visual a seguir disposta, constituída pela seleção que fizemos de nossos registros e de extratos editados das aquisições do acervo da biblioteca CORSAN-SITEL. 
Fotografia 3 (autoras, 2018)

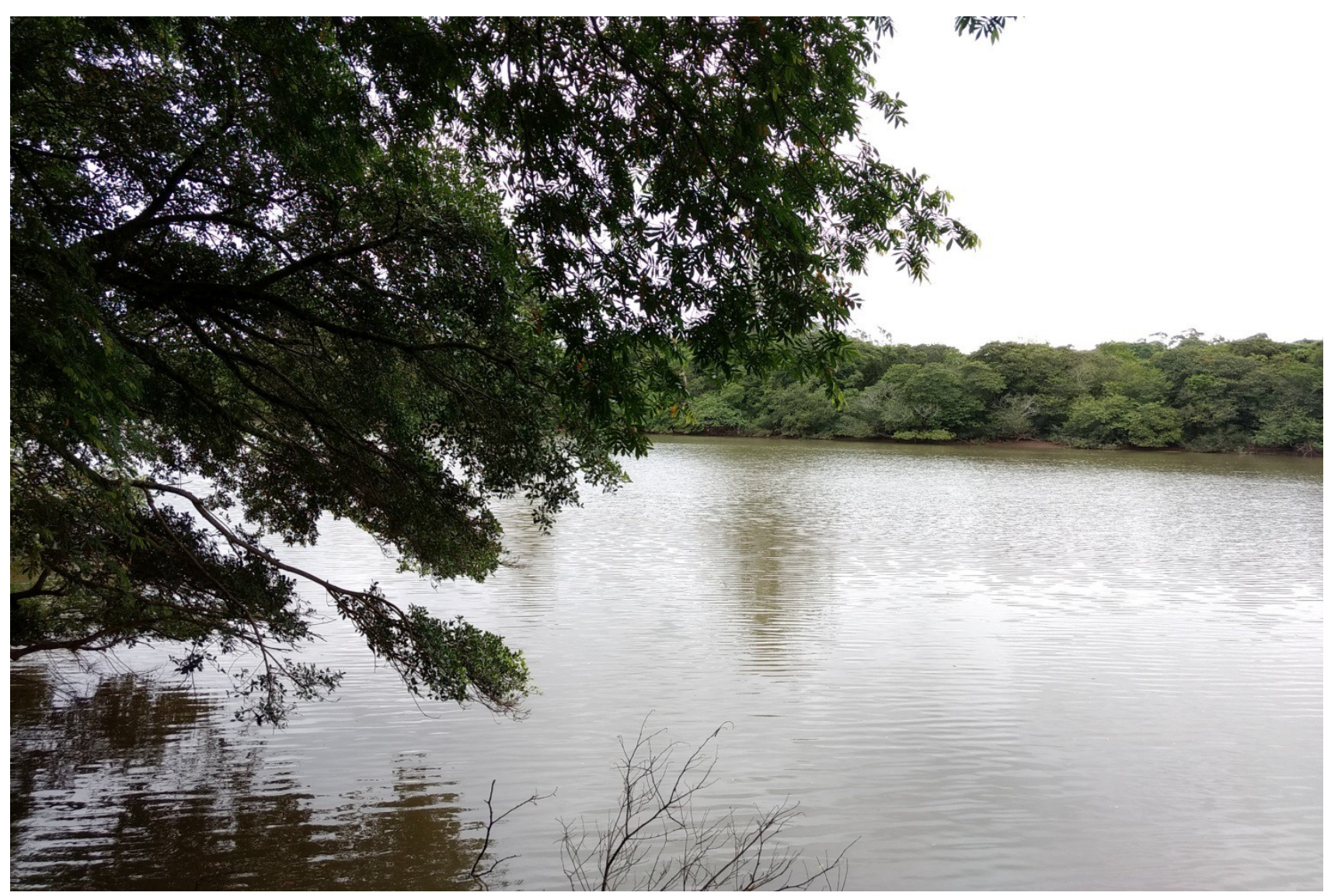

Rio Caí, margem direita. 
Fotografia 4 (reprodução das autoras do APSITEL, 2018)

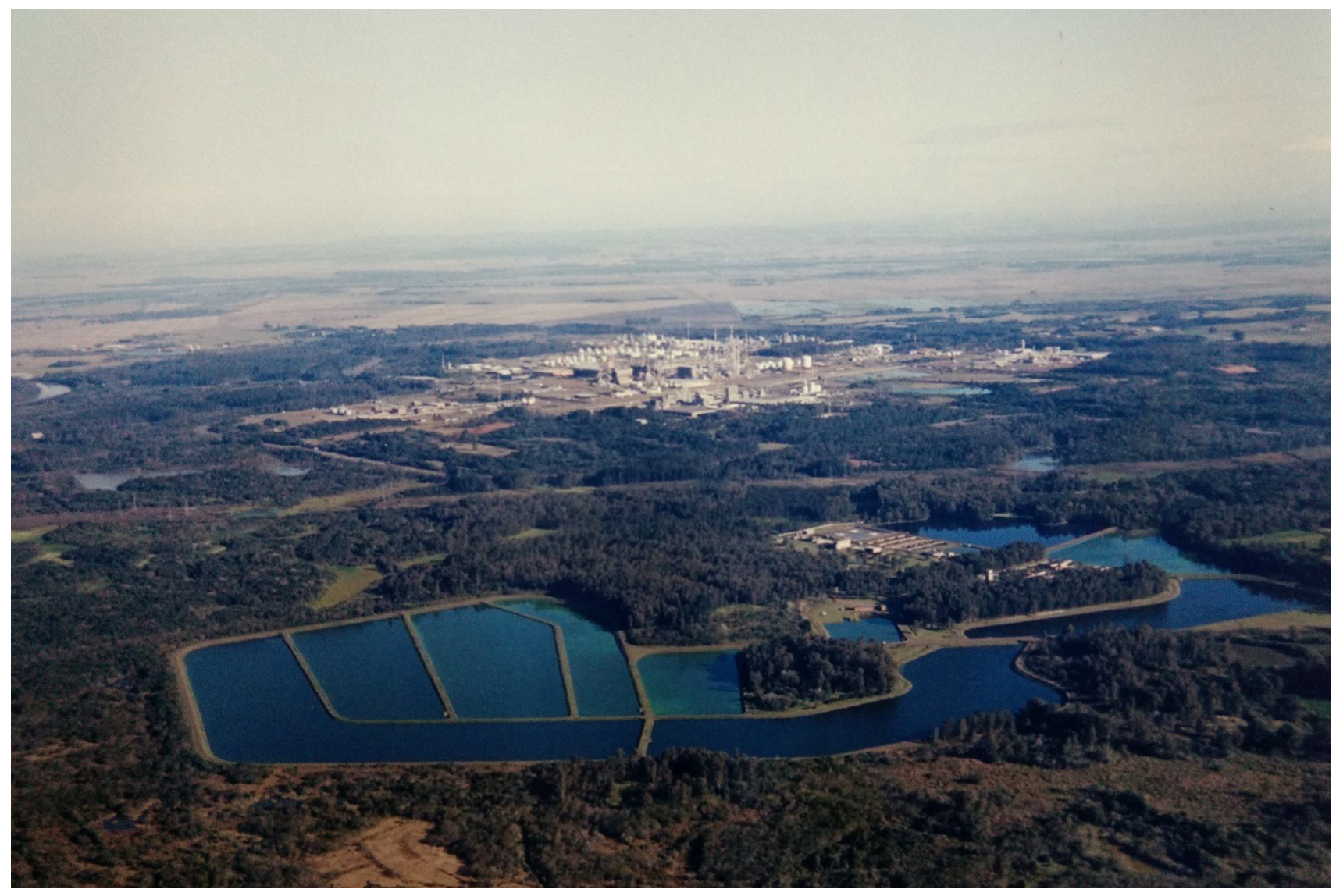

Rio Caí, seguindo o fluxo da água: o SITEL, depois o Complexo Industrial, por fim a sua captação de água. 
Fotografia 5 (autoras, 2018)

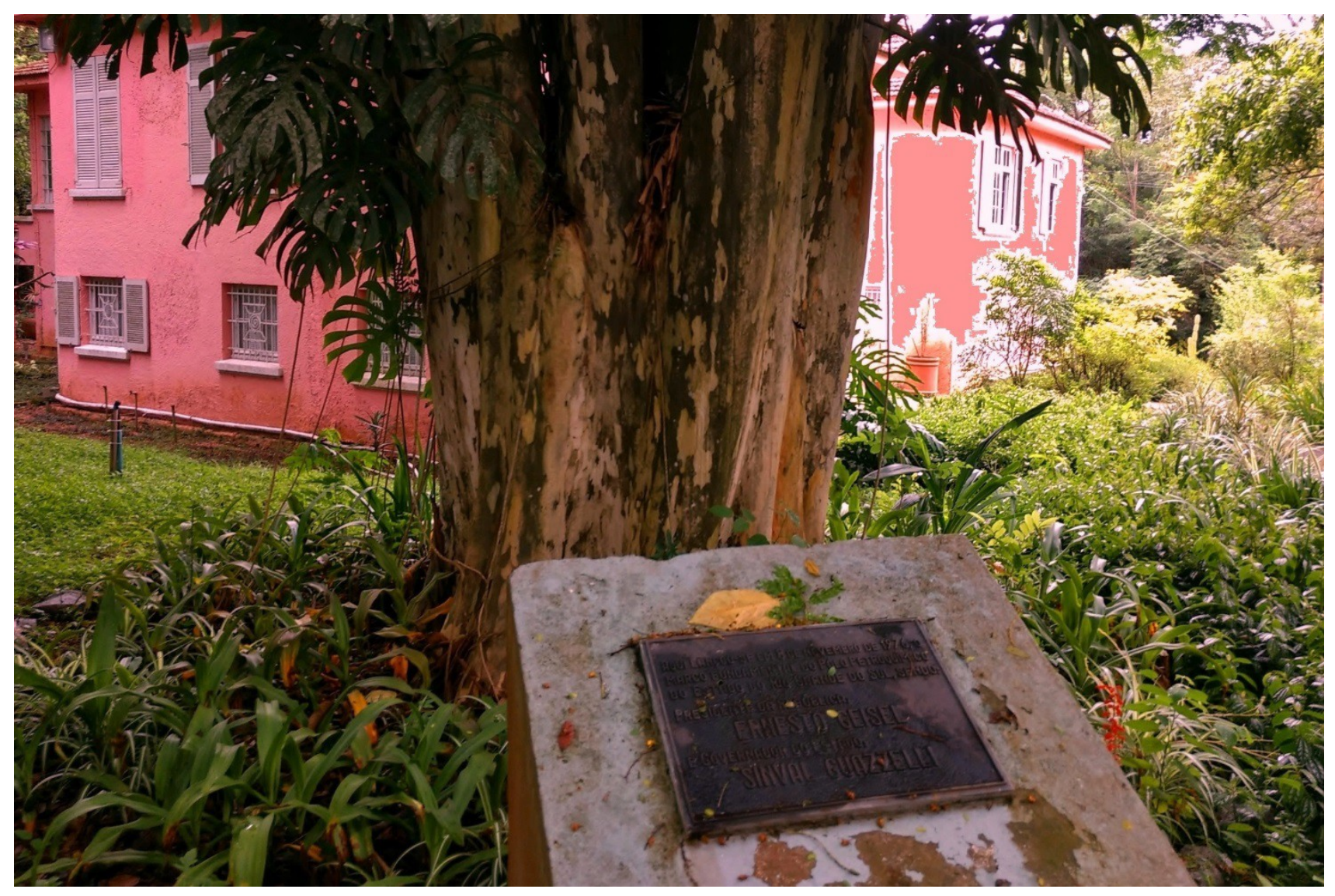

O marco fundamental na Casa Rosa. 


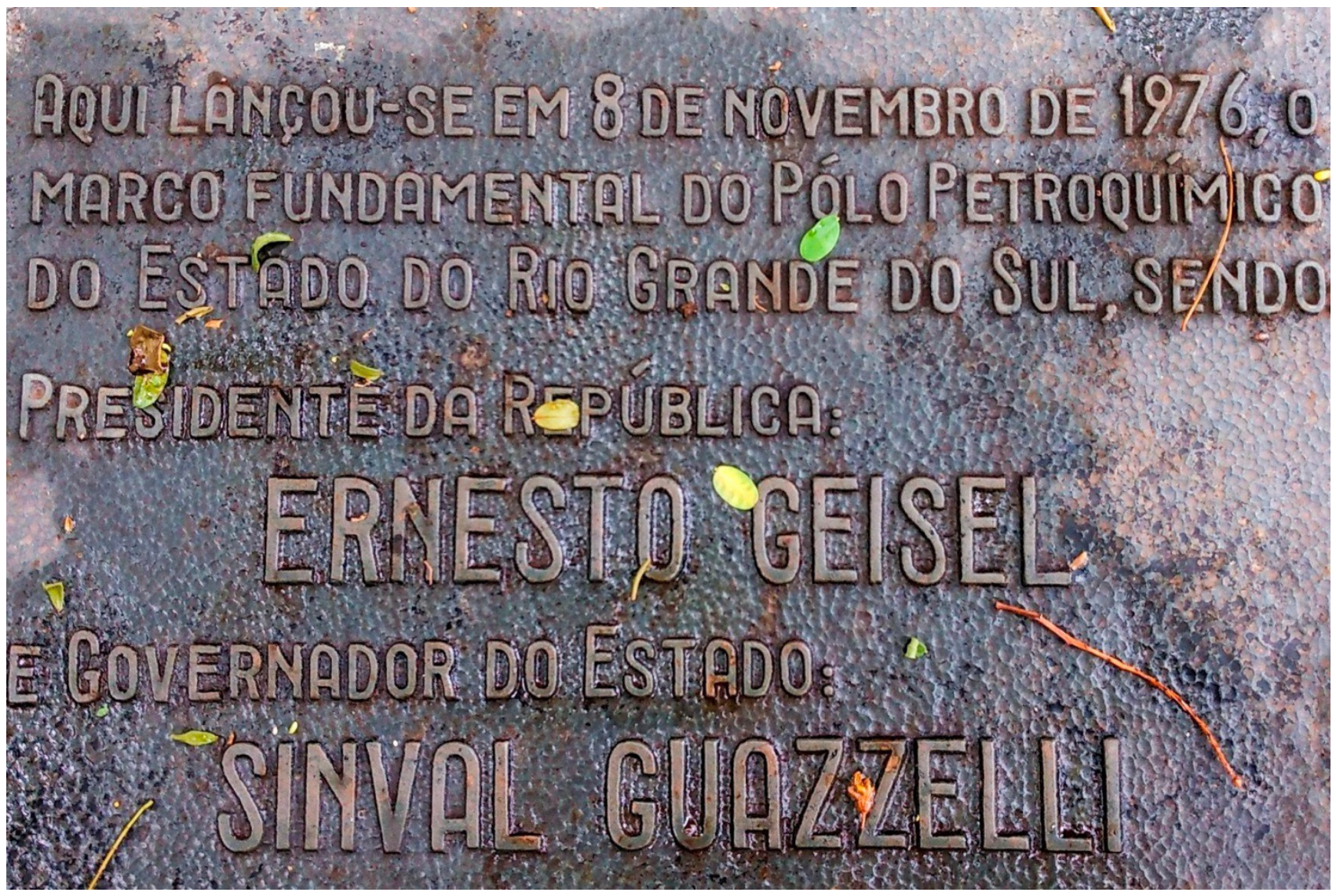

General e Presidente: o padrinho político do complexo petroquímico. 


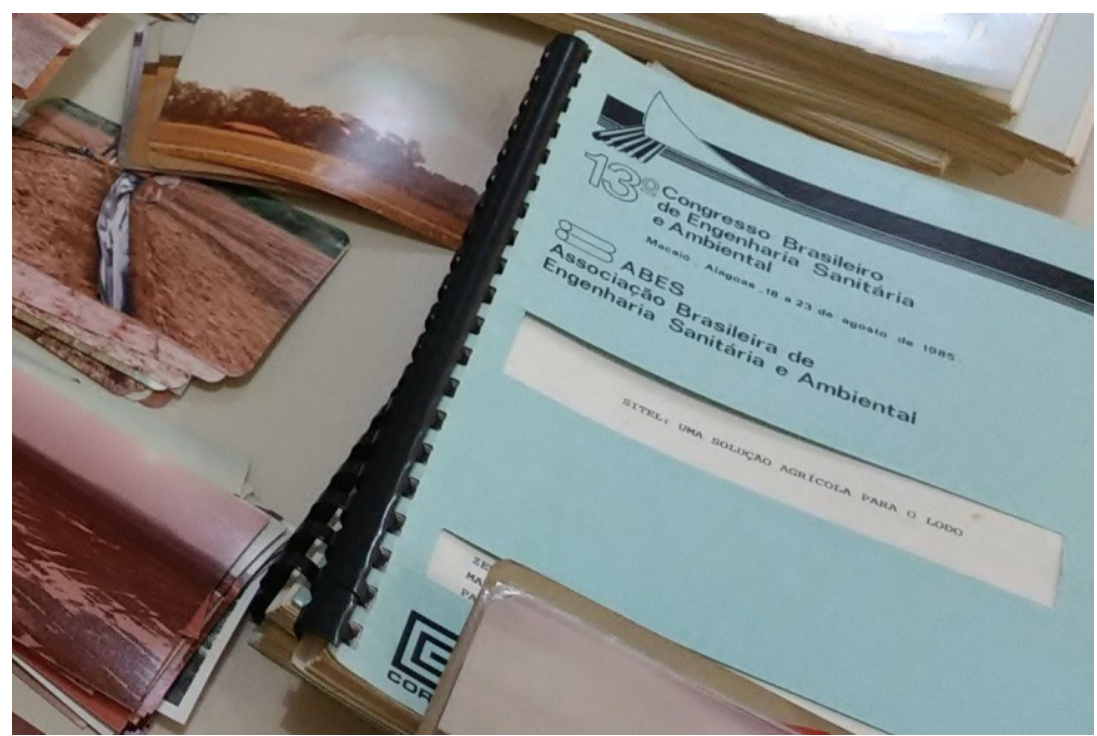

Engenharia e imagem.

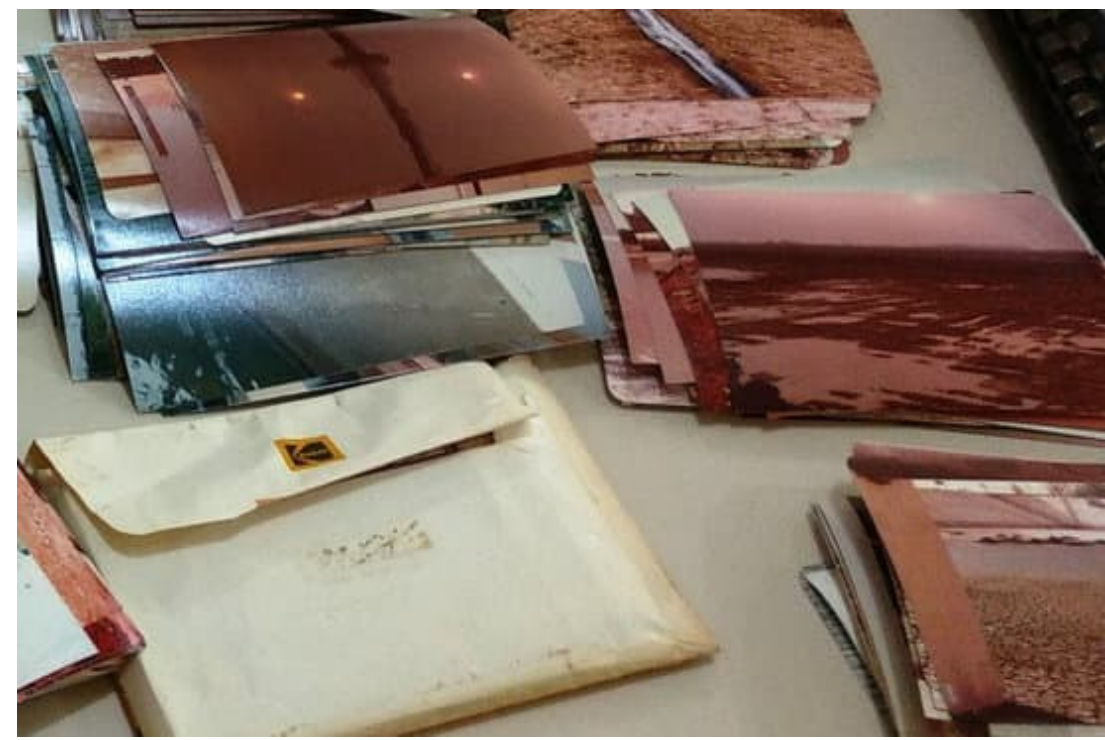

Acervo histórico precioso do SITEL. 
Mosaico de fotos 2 (autoras, a partir de suas reproduções do APSITEL, 2018)

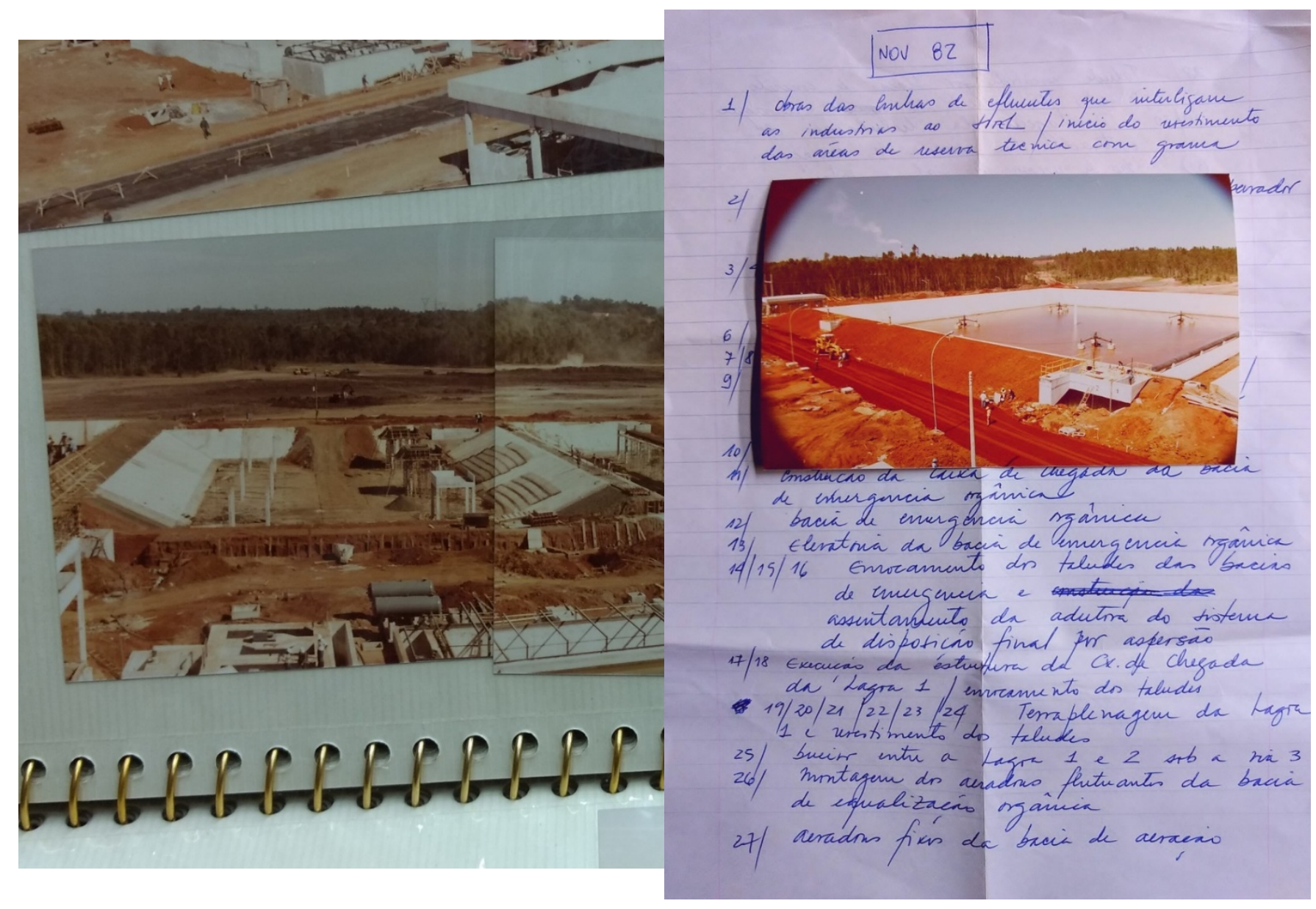

Registros da obra do SITEL (1982-1982): proteção do rio Caí em marcha. 
Fotografias 9 e 10 (reprodução das autoras do APSITEL, 2018)

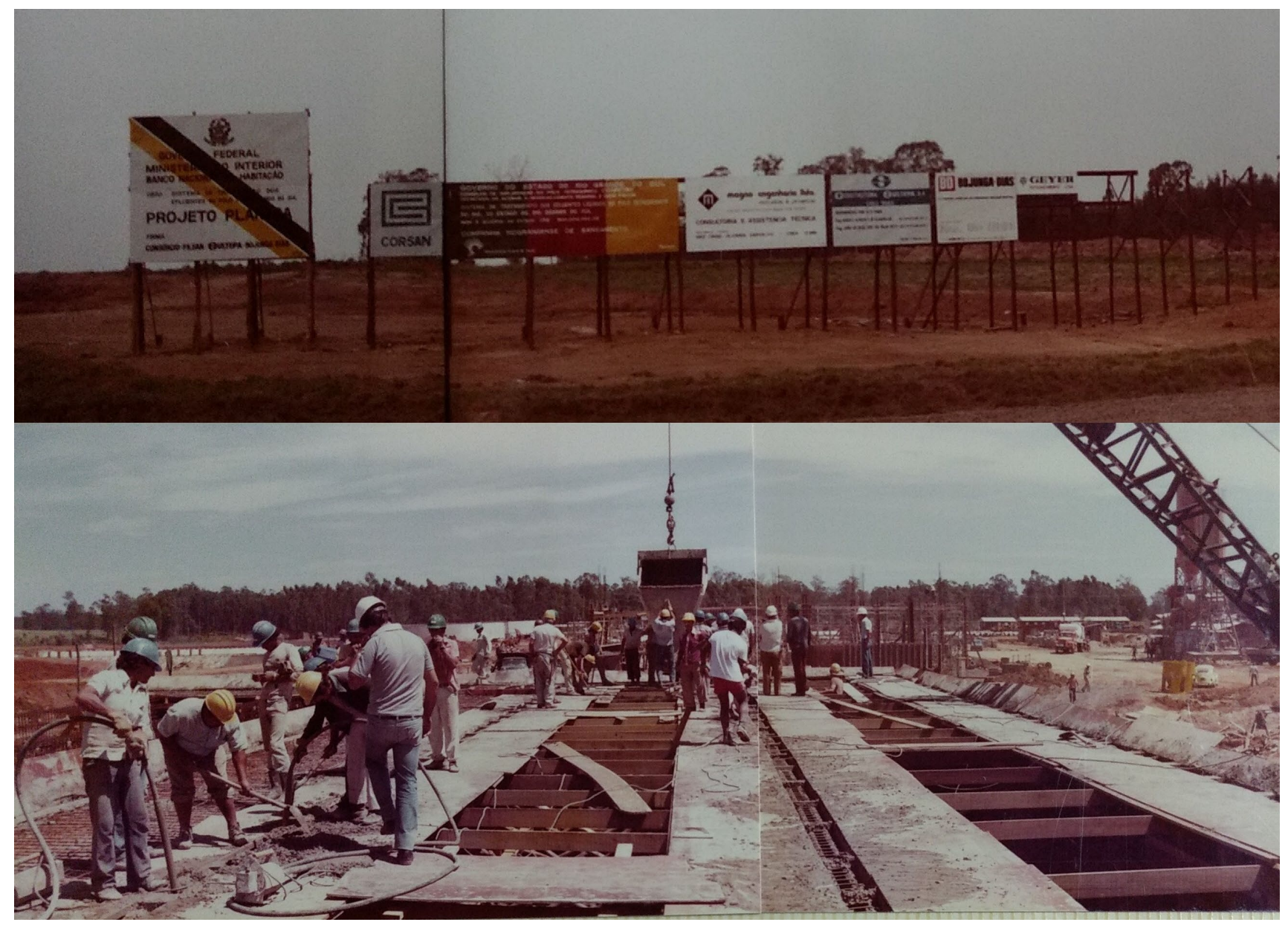

Parceiros do II Plano Nacional de Desenvolvimento. 
Fotografia 11 (reprodução das autoras do APSITEL, 2018)

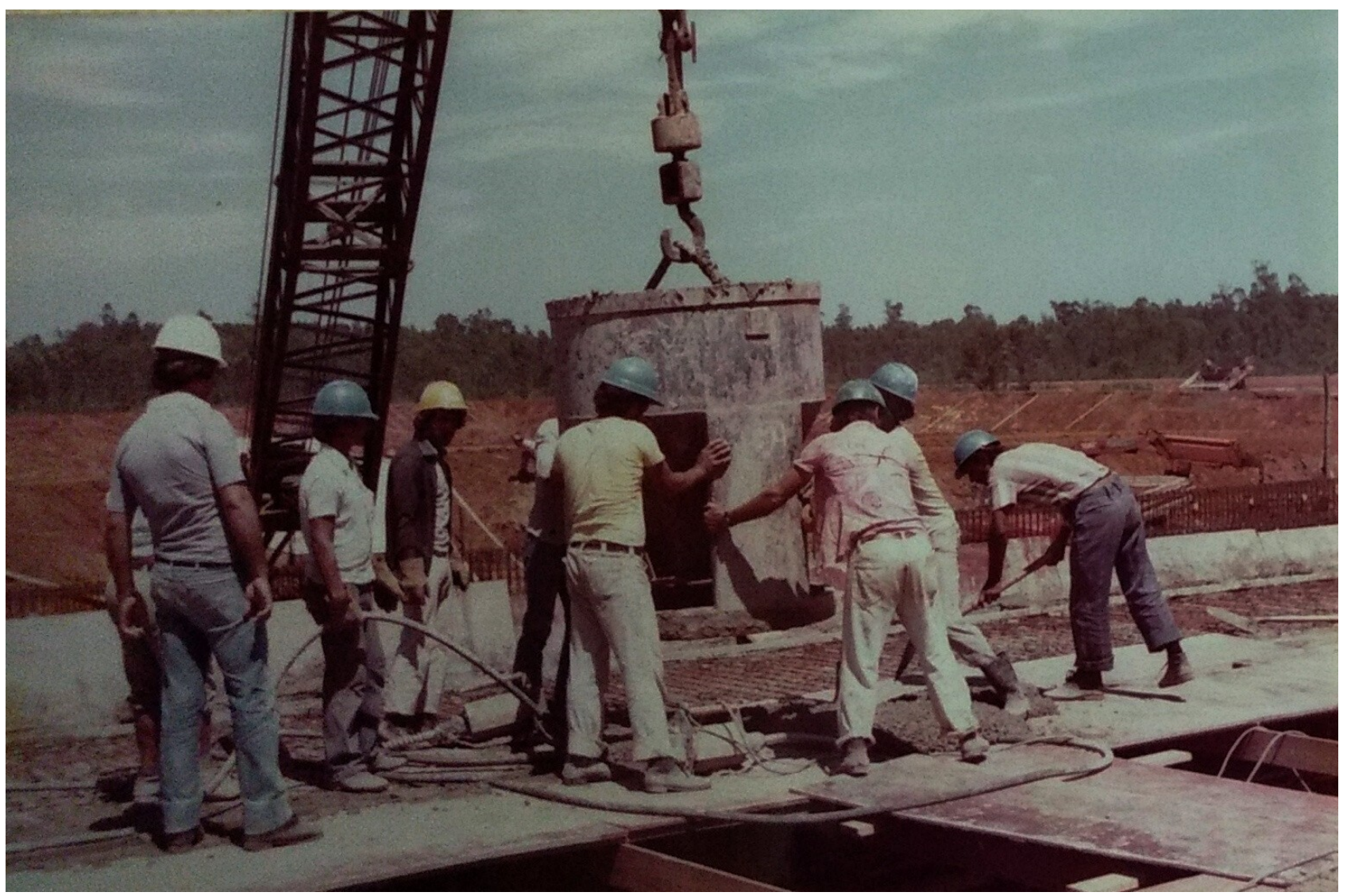

O uniforme é a roupa de cada um, para a tarefa em conjunto. 
Fotografia 12 (reprodução das autoras do APSITEL, 2018)

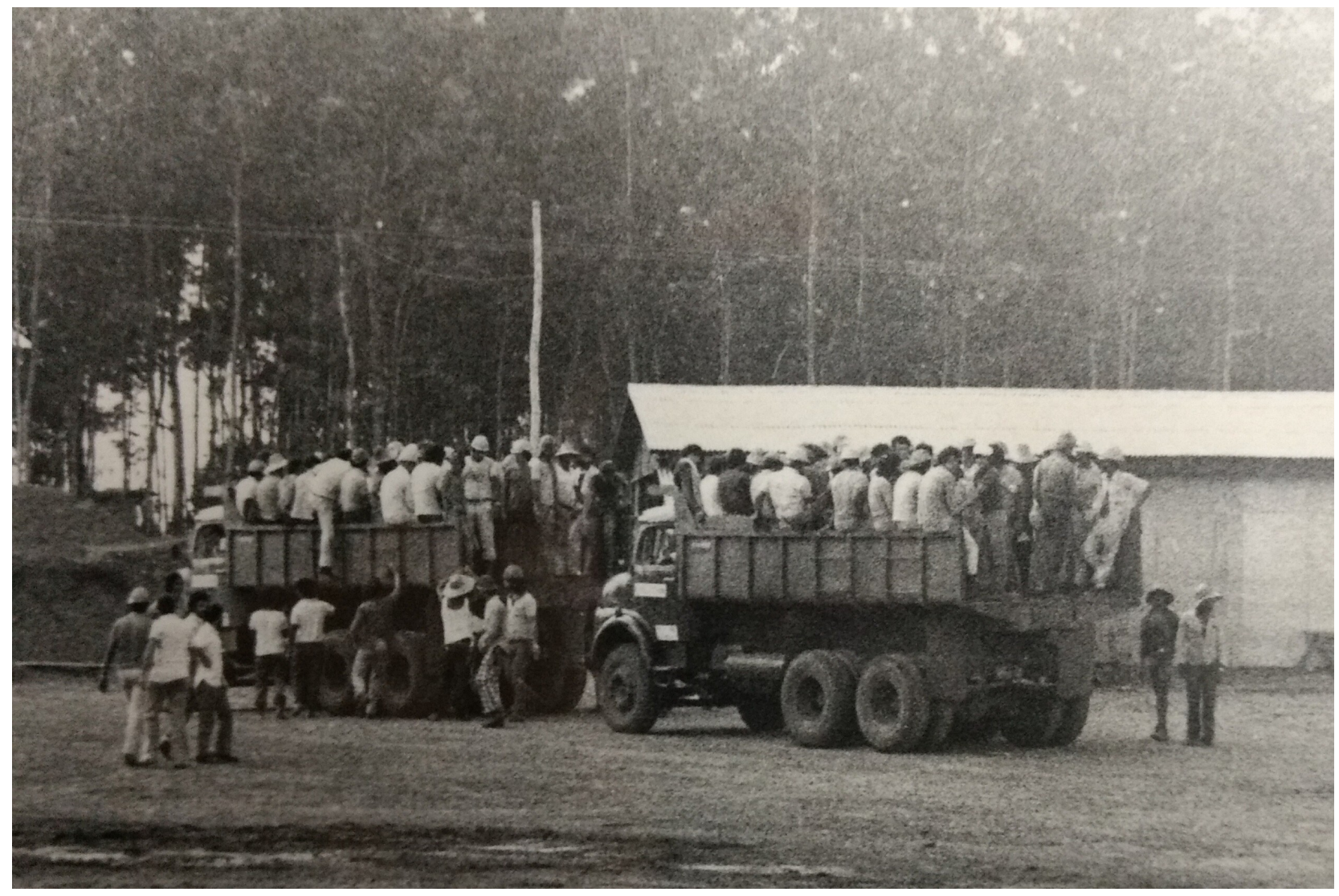

Trabalhadores em transporte na obra. 


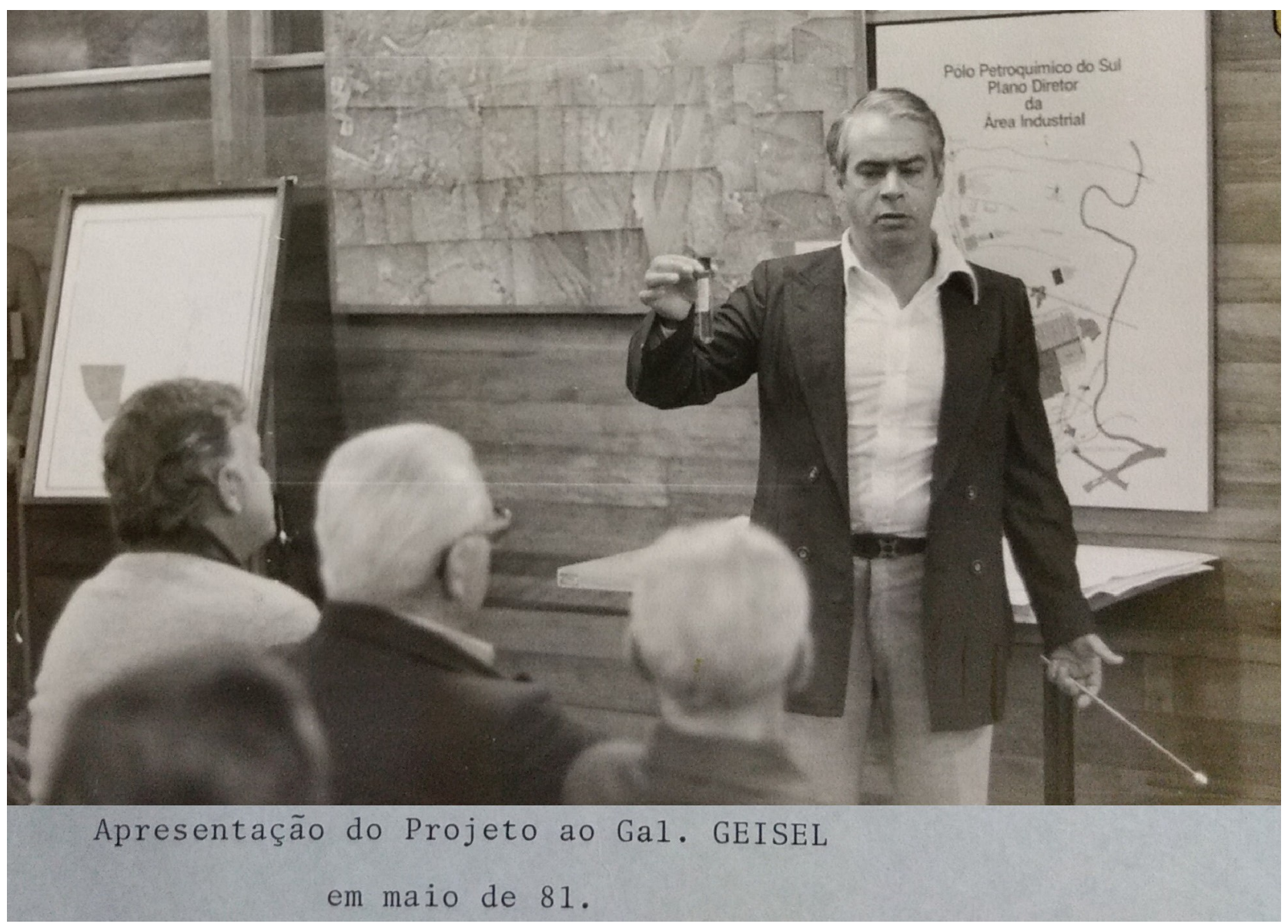

Explanando ao padrinho do Polo Petroquímico, Paraguassú Garcia Flores, coordenador do projeto do SITEL. 


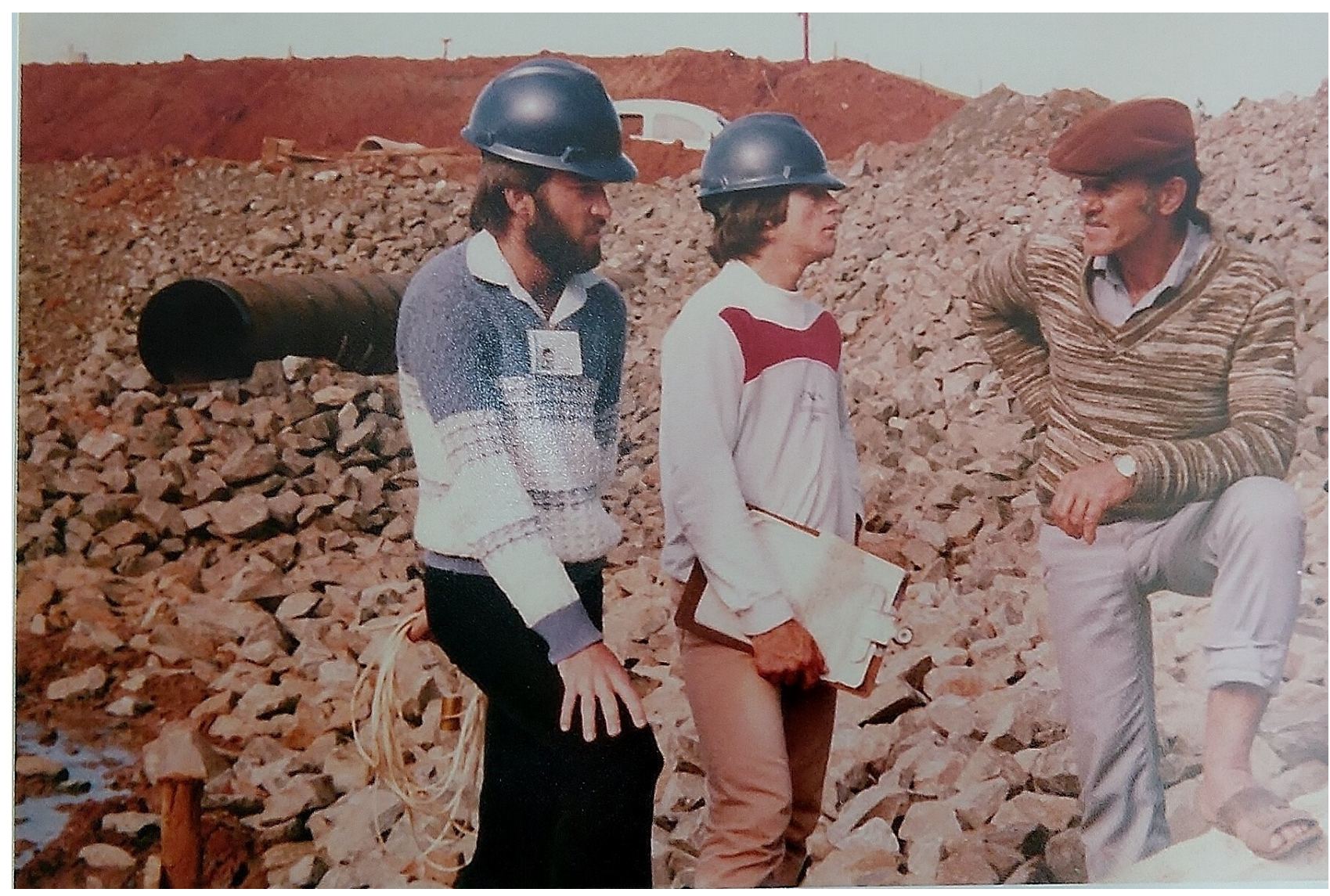

16 de novembro de 1982, chegada do primeiro efluente do Polo Petroquímico para tratamento no SITEL. 
Fotografia 15 (reprodução das autoras do APSITEL, 2018)

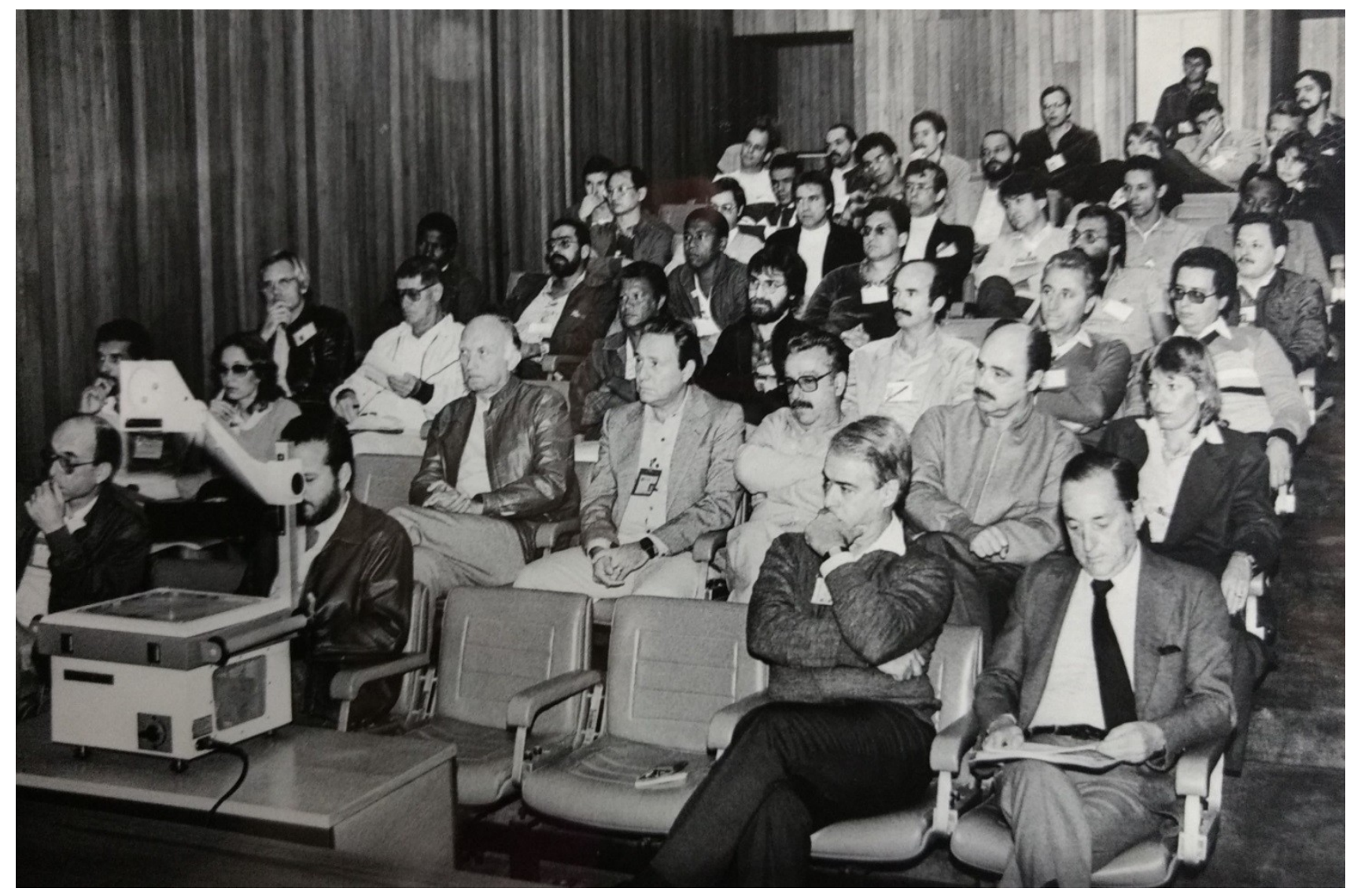

Na reunião técnica em 1986, pessoas que de alguma forma integram a pesquisa: do Polo Petroquímico, Percy Louzada de Abreu e Eduardo McMannis Torres e do SITEL (SUPE/CORSAN) Paraguassú Garcia Flores, Zeno Simon e Ellen Martha Pritsch. 


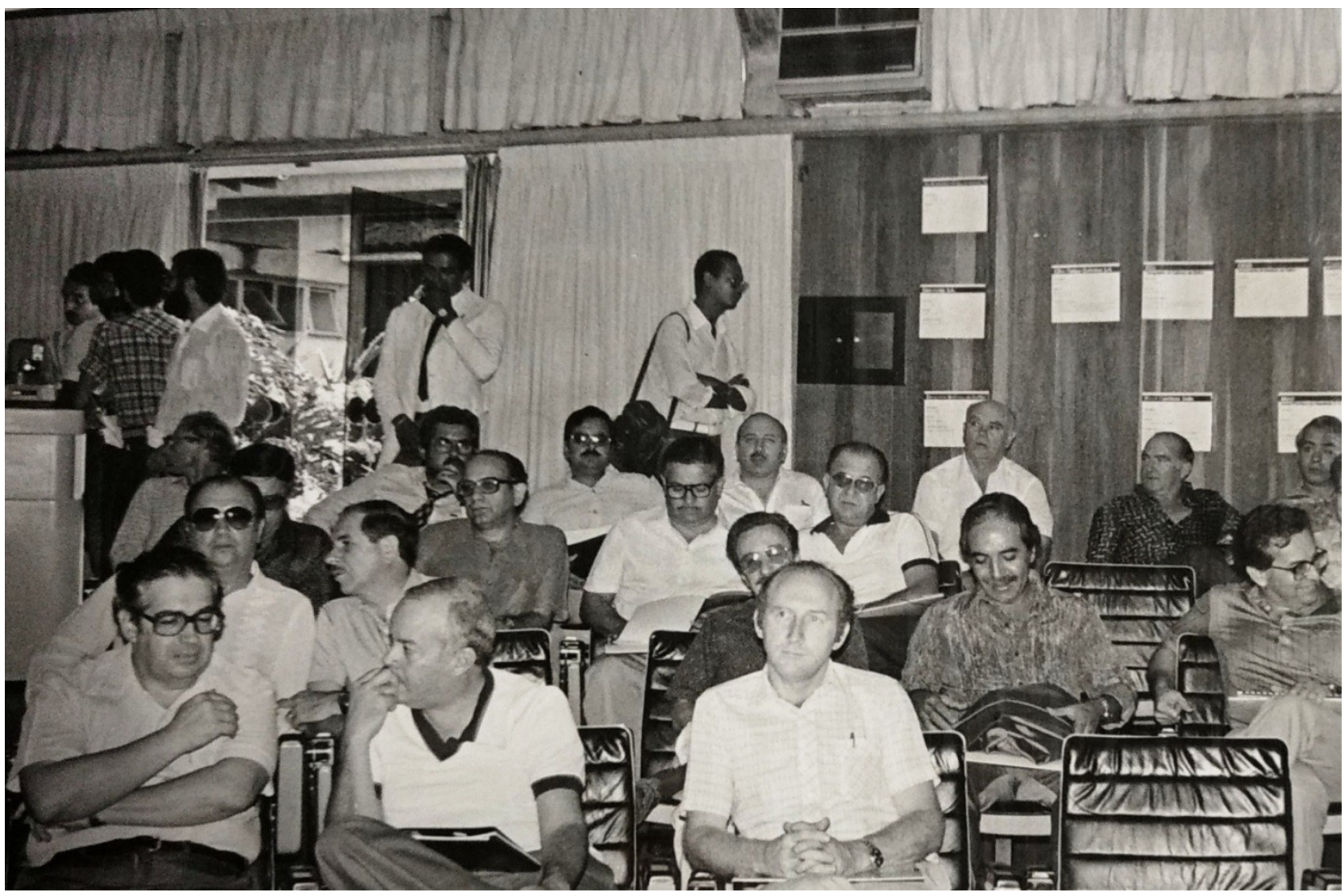

Registro dos debates públicos em Porto Alegre, mais "águas abaixo", sobre a polêmica ambiental em torno do projeto. Na primeira fila, a esquerda da foto, identifica-se o químico, geneticista e ambientalista Flávio Lewgoy. 
Fotografias 17 e 18 (reprodução das autoras do APSITEL e autoras, 2018)
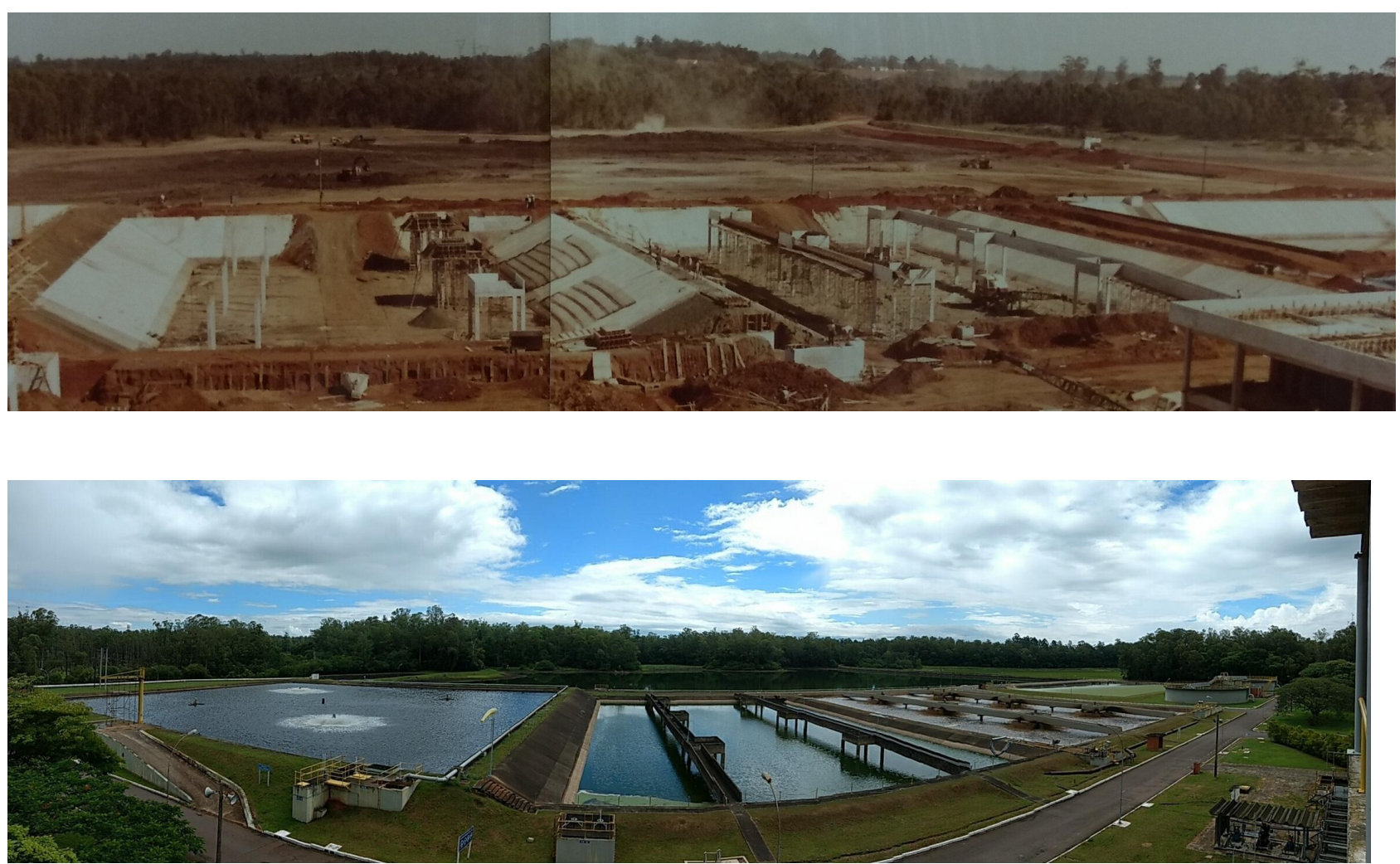

O trabalho de campo permite cotejar vistas panorâmicas do SITEL: 1982 e 2018. 


\section{Uma vista do rio Caí: políticas e acervos em trânsito perigoso}

Apoiando-nos em Guran (2011:82; 95), entendemos o todo dessa contribuição como "uma montagem ordenada de imagens fotográficas de modo a produzirem sentido". Concatena dois discursos distintos, uma vez que ela apoia-se em relação ao que fomos explicando, bem como encontra algum amparo nas legendas que escolhemos para cada uma das imagens constituídas. Temos a intenção de transmitir parte do que esta proximidade resultante do trabalho de campo, por curta que tenha sido, nos causou. Segundo Guran (2011:84), estivemos fotografando "para contar": nossa busca empírica, detalhando a maneira pela qual decidimos isso fazer. Procuramos seguir, contudo, o vaie-vem que o autor apregoa necessário, entre a reflexão escrita e o espaço aberto pela imagem.

Como já enfatizamos, parte importantíssima dessa narrativa, e de nosso trabalho é possível devido a esses dois já citados acervos públicos (o Acervo Público do SITEL administrado pela CORSAN a Biblioteca Pública da FEPAM), ambos pertencentes à esfera estadual de governo.

Segundo Paes (2004:24), “arquivo público é o conjunto de documentos produzidos ou recebidos por instituições governamentais em âmbito federal, estadual ou municipal, em decorrência de suas funções específicas administrativas, judiciarias ou legislativas". Em nosso caso, trata-se de documentação da esfera administrativa, bastante variada em tipologia. Nos dois acervos, chamou-nos a atenção o estado de conservação e disposição dos documentos.

É importante informar que esse nosso trabalho ocorreu em momento de extinção de fundações do Estado do Rio Grande do Sul, entre elas a Fundação Zoobotânica, cujo prédio da sede administrativa à época de nossa visita recém havia recebido a BFEPAM.

Em nossa visita pudemos perceber o clima tenso em função das incertezas deste processo, que não se resolveu sem resistência de funcionários, jornalistas, ambientalistas e opositores da extinção em geral. Com a extinção da FZB, todo um patrimônio estava sob ameaça, não só arquivístico, mas histórico e ambiental, pois a fundação abrigava instituições importantíssimas, como o Jardim Botânico, o Parque Jardim Zoológico e o Museu de Ciências Naturais, além de ser responsável pela pesquisa, promoção e conservação da biodiversidade no Rio Grande do Sul ${ }^{3}$.

\footnotetext{
${ }^{3}$ A extinção da FZB pode ser pensada como "um processo que se inscreve como feição local e regional de um contexto macro ético, político e econômico de mundialização e financeirização da economia e sua
} 
Apesar de todos os esforços e cuidados dos funcionários dos acervos, isso não é suficiente para garantir sua preservação. Nesse sentido, seria necessária uma política pública arquivística, entendida como:

[...] o conjunto de premissas, decisões e ações - produzidas pelo Estado e inseridas nas agendas governamentais em nome do interesse social - que contemplam os diversos aspectos (administrativo, legal, científico, cultural, tecnológico, etc.) relativos à produção, ao uso e à preservação da informação arquivística de natureza pública e privada". (Jardim, 2006:38).

Infelizmente, a preservação de acervos e museus no Brasil é algo precário, pois a sociedade não os considera importantes como lugares de memória (Nora, 1993), que guardam registros valiosos do passado. Podemos citar como exemplo disso o recente episódio trágico do incêndio que atingiu boa parte do acervo do Museu Nacional, no Rio de Janeiro, em setembro de 2018.

No momento em que finalizamos este artigo, a extinção da FZB está oficializada, com a baixa no CNPJ, em 15 de maio de 2020 (Tentardini, 2020). Não sabemos os rumos que serão tomados em relação aos acervos da instituição. Resta-nos argumentar sobre a necessidade de sua preservação, bem como do acervo CORSANSITEL. Para isso, seria necessária uma política pública de conservação de acervos que garantisse a manutenção e acesso aos documentos, tão preciosos para a escrita da história ambiental no Rio Grande do Sul.

\section{Considerações finais}

Ao longo das atividades de nossa pesquisa notamos muitas coisas, por intermédio de nossos distintos e particulares modos de ver: vários termos que constam nos documentos passam a ter outros significados. Pessoas morrem, empresas desaparecem - ou mudam de nome. As estruturas envelhecem. Placas somem, outras aparecem, políticas igualmente.

Poderíamos escrever longamente sobre as imagens que aqui trouxemos. Contudo, não entendemos como sendo esse o objetivo desta contribuição, que não é exatamente etnográfica. Estamos, sim, descrevendo o nosso trabalho de campo. Porém, não somente para comprovar que "estivemos lá": explicamos nossas razões e caminhos

crise, a qual impõe a privatização do Estado e o desmonte das políticas públicas trabalhistas e ambientais, a chamada "flexibilização" da legislação protetora do trabalho e do meio ambiente" (Dubiela, 2019:16). 
decisórios para isso, bem como o modo pelo qual realizamos tal incursão ao nosso principal mote empírico de estudo.

Cumpre finalmente comentar as edições das imagens que escolhemos aqui apresentar: foram feitas por nós mesmas, contudo respeitando o tom de época em que os registros foram feitos - a cor do próprio arquivo como encontrado no seu modo de atual de ser. Não nos pareceu igualmente apropriado eliminarmos as marcas das justaposições fotográficas realizadas por atos físicos de recorte e junção. Muito menos deixamos de escolher fotos aqui publicadas por algumas características que poderiam ser interpretadas como "má qualidade técnica": sua preciosidade de registro ímpar, e por isso, de imenso valor narrativo, fala de momentos históricos importantíssimos. Como um sinal disso, fazemos notar nossa explícita edição das cores da Casa Rosa: reforça, retirado de seu quadro tonal mesmo, a cor de suas paredes, o que talvez seja o único resquício de seu proprietário e espírito original. Ao mesmo tempo, esse nosso deliberado ato avisa de nossa presente interferência. Como não podia ser diferente, afinal: para construirmos essa narrativa, 'sujamos nossas botinas', na tarefa de rever 'um passado que já teve outras cores'. O tempo, esse implacável agente em seu atuar misterioso nesse mundo de muitos lugares e interesses, deixa vestígios por onde passa.

Esse relato desvela e compartilha a riqueza de um acervo que não é só técnico: fala da história, a partir da perspectiva ambiental, de um emblemático projeto de desenvolvimento brasileiro, que foi moldado por inesperada força social em época de ditadura civil-militar.

Embora guardem documentos preciosos, como constatamos, atualmente não existe política de conservação para esses arquivos. E muito menos de sua fácil e garantida disponibilidade pública: automatismo que deveria existir, uma vez que contêm resultados decorrentes de atividades de licenciamento ambiental. Fato é que, apesar dos cuidados ainda remanescentes, entre a teimosia e a abnegação de alguns funcionários mais antigos, ambos no momento abrigam, em condições de fragilidade física e institucional, documentos únicos e não digitalizados. Se houver algum dano, o seu conteúdo ficará perdido para sempre. Caso isso ocorra, muito perderemos.

Por último, exatamente pela sua relevância na conformação dessa ação de conhecimento, trazemos novamente a visão das águas e sua relação com esse Complexo Industrial. Vimos como os meandros do rio Caí, nesse trecho já tão aparentemente calmo, vão paulatinamente servindo às necessidades das indústrias. Em que pese o 
tratamento sofisticado e o efetivo cumprimento da pioneira lei Lélio Souza ${ }^{4}$, suas margens sofrem influência de seus efluentes e resíduos, para logo depois disponibilizar água para a captação necessária e indispensável para as atividades industriais desse lugar.

Por fim, se é necessário evitar a hipocrisia da negação das atividades industriais no contexto em que vivemos, igualmente é fundamental admitir que os cuidados de proteção ambiental continuam sendo motivo de batalha. O perfil do aglomerado industrial tem mudado ao longo do tempo, pelo que entendemos da visita e das entrevistas feitas. E nesse movimento, o entrecruzar de políticas de toda sorte não configura garantia de espécie alguma. Olhando pelo retrovisor da história ambiental e dos projetos de desenvolvimento, vê-se o quanto imprescindível é a escuta do muito que o rio Caí tem a dizer a respeito dessa complexidade.

\footnotetext{
${ }^{4}$ Trata-se do Decreto Legislativo n ${ }^{\circ} 3.601$, de 30/12/1976. De autoria do então deputado estadual Lélio Souza, o decreto estipulava que "os resíduos industriais do III Polo Petroquímico, qualquer que seja o processo de tratamento adotado, serão conduzidos a um ponto de destino final, de onde não possam ter acesso às águas do delta e do estuário do Guaíba, assim como às de seus afluentes ou cursos formadores" (RS, 1976).
} 


\section{REFERÊNCIAS}

ACSELRAD, Henri. Ambientalização das lutas sociais - o caso do movimento por justiça ambiental. Estudos Avançados, São Paulo, v. 24, p. 103-119, 2010.

ALMEIDA, Jalcione. Da ideologia do progresso à idéia de desenvolvimento (rural) sustentável. In: ALMEIDA, Jalcione e NAVARRO, Zander. (Org.). Reconstruindo a agricultura: ideias e ideais na perspectiva do desenvolvimento rural sustentável. Porto Alegre: Editora da UFRGS, 1997.

DUBIELA, Diogo. “A FZB NÃO TEM PREÇO, TEM VALOR!” Memória, patrimônio e imagem no processo de extinção da Fundação Zoobotânica do Rio Grande do Sul. Dissertação de Mestrado. Porto Alegre, PPG Antropologia Social, UFRGS, 2019.

FLORIANI, D. Marcos Conceituais para o Desenvolvimento da Interdisciplinaridade. In: PHILIPPI JR., A. TUCCI, C. E. M., et al. (Org.). Interdisciplinaridade em Ciências Ambientais. São Paulo: Signus Editora, 2000. p. 95-107.

GERHARDT, Clayton Henrique; ALMEIDA, Jalcione. A dialética dos campos sociais na interpretação da problemática ambiental: uma análise crítica a partir de diferentes leituras sobre os problemas ambientais. Ambiente \& Sociedade. Campinas. v. 8, n. 2, p. 53-84, Dez. 2005.

GURAN, Milton. Considerações sobre a constituição e a utilização de um corpus fotográfico na pesquisa antropológica. discursos fotográficos, v.7, p. 77-106, Disponível em: http://www.uel.br/revistas/uel/index.php/discursosfotograficos/article/view/9215. Acesso em: 24 maio 2020.

JARDIM, José Maria. Políticas públicas arquivísticas: princípios, atores e processos. Arquivo \& Administração, Rio de Janeiro, v.5, n.2, p. 5-16, jul./dez. 2006.

NORA, Pierre. Entre memória e história: a problemática dos lugares. Projeto História. São Paulo, nº 10, dez. 1993.

PAES, Marilena Leite. Arquivo: teoria e prática. Rio de Janeiro: FGV, 2004.

PEREIRA, Elenita Malta, RIBEIRO, Claudia. (no prelo). Proteção das águas e desenvolvimento em debate no sul do Brasil: o conflito ambiental no Polo Petroquímico de Triunfo (1975-1982). Estudos Iberoamericanos, Porto Alegre, vol. 48. n. 2, MaioAgosto 2021. 
RIO GRANDE DO SUL. Decreto n. 24.113 de 10 de outubro de 1975. Declara de utilidade pública, para fins de desapropriação do domínio pleno, uma área de terra situada nos municípios de Triunfo e Montenegro destinada à implantação do Complexo Petroquímico do Sul - COPESUL. 1975. Disponível em: < http://www.al.rs.gov.br/legis/M010/M0100018.asp?Hid_IdNorma=33354\&Texto=\&Ori gem=1>. Acesso em: 15 ago. 2019.

Decreto Legislativo n. 3.601, de 30 de dezembro de 1976. Aprova convênio de promessa de refinanciamento celebrado entre o BNH e o Rio Grande do Sul, especificamente o apoio da primeira etapa da implantação do Polo Petroquímico do estado do RS, nos município de Montenegro e Triunfo. 1976. Disponível em: < http:/www.al.rs.gov.br/legis/M010/M0100018.asp?Hid_IdNorma=31786\&Texto=\&Ori gem=1>. Acesso em: 15 Ago. 2019.

. Plano de Bacia - Bacia Hidrográfica do rio Caí. Relatório Temático A.1.

Dinâmica Social, 2007a. Disponível em: <https:/www.sema.rs.gov.br/g030-baciahidrografica-do-rio-cai>. Acesso em: 25 maio 2020.

. Plano de Bacia - Bacia Hidrográfica do rio Caí. Relatório Temático A.2.

Diagnóstico da Disponibilidade Hídrica, 2007b. Disponível em:

$<$ https://www.sema.rs.gov.br/g030-bacia-hidrografica-do-rio-cai>. Acesso em: 25 maio 2020.

SILVA, D. J. O Paradigma Transdisciplinar: uma Perspectiva Metodológica para a Pesquisa Ambiental. In: PHILIPPI JR., A. TUCCI, C. E. M., et al. (Org.). Interdisciplinaridade em Ciências Ambientais. São Paulo: Signus Editora, 2000. p. 7194.

TENTARDINI, Cleber Dioni. Fundação Zoobotânica do Rio Grande do Sul está oficialmente extinta. Jornal Já, Porto Alegre, 15 de maio de 2020. Disponível em: http://www.jornalja.com.br/geral/fundacao-zoobotanica-do-rio-grande-do-sul-estaoficialmente-extinta/> . Acesso em: 20 maio 2020.

WORSTER, Donald. Para fazer história ambiental. Estudos Históricos, Rio de Janeiro, vol. 4, n. 8, 1991, p. 198-215. 
Recebido: 29/05/2020

Aprovado: 04/09/2020 